\title{
Use of Learning Management Systems (LMS) As A Network Learning Media (Online) During the Covid-19 Pandemic
}

\author{
Dody Sumardi*, Nunuk Suryani, Akhmad Arif Musadad \\ Master Program of Educational Technology, Faculty of Teacher Training and Education, Sebelas Maret \\ University, Indonesia
}

${ }^{*}$ Corresponding author:

E-mail:

dodysumardi72@gmail.com

\begin{abstract}
The Covid-19 coronavirus pandemic that has hit the world has now changed the order of human life, every activity uses masks, maintains distance, does not gather, and washes hands. The government does not allow face-to-face learning in the classroom, so learning is carried out online (online), teachers provide learning using several e-learning platforms that are available as long as they are supported by internet facilities. The use of these different platforms resulted in the learning process being less than optimal due to the lack of coordination between teachers, management, and students. Learning scheduling which is carried out individually is not coordinated, this makes it difficult for teachers and students to start learning and is verified/monitored by management to ensure the quality of learning. Students find it difficult to know and repeat the subject matter that has been implemented. This online learning process needs a media that can manage all learning activities starting from planning, implementation to evaluation that makes it easier for management, teachers, and students. The method in this writing is the method of literature from experts and some research results that are descriptive-analytical. LMS media is expected to be able to manage the learning process that begins with scheduling, subject matter and evaluation easily which can be accessed and studied by students online using the LMS. Management can control and monitor the learning process, and parents can also participate in monitoring, following, and directing learning.
\end{abstract}

Keywords: Covid-19 pandemic, Learning Management System (LMS), online, Learning

\section{Introduction}

Currently, the world is experiencing a coronavirus pandemic or better known as Covid-19 or SARS-CoV-2 (Severe acute respiratory syndrome coronavirus 2), this is a new variant of the coronavirus that causes the transmission to humans. This dangerous virus can infect anyone, such as the elderly, adults, children, and even babies, including pregnant women and breastfeeding mothers. This virus is very dangerous and some people who are exposed do not show symptoms or in the term people without symptoms (OTG), for people who are physically weak or have comorbidities it will be fatal for them.

This dangerous and easily contagious epidemic was anticipated by the world by limiting everyone to leave the house or go to places where there were large crowds of people, even if they were forced to leave the house, they had to wear a very tight mask, this was to avoid the transmission of the disease. The world of education has been affected by the coronavirus outbreak, so this condition greatly disrupts the teaching and learning process of students at school. The central government through the Ministry of Education and Culture issued circular letter number 4 of 2020 which instructs the teaching and learning process to be carried out from 
home in the online form (on the network) during the covid-19 pandemic or prohibits direct faceto-face learning in class.

Learning is carried out online/in a network (online), teachers and students do not meet faceto-face but through internet-based electronic media (e-learning) but there is still interaction between teachers and students that influence each other. As stated by Rusman (2011) that elearning is all learning activities that use the help of electronic technology tools, teachers and students interact with each other even though they are not in the same place and are possible at different times.

Advances in information technology have enabled online learning using several media, among others, as stated by Rusman, (2011) many electronic technologies are used such as the internet, intranets, audio or videotapes, broadcasting via satellite, interactive television, and CDROM. ROMs. Currently, there are also many e-learning platforms used by teachers or educational institutions, both paid and free, including Moodle, Edmodo, Google Classroom, Google form, Camtasia, Schoology, and many more. E-learning is not a substitute for classroom learning, it is a compliment as stated by Shank (2008) that E-learning plays a role in complementing conventional classrooms.

Disruption of learning like this is also experienced by SMP N 6 Semarang so that the learning process is carried out online, students learn from their homes using computers, laptops, or smartphones owned by them with internet facilities, and teachers upload teaching materials through the platform. His masters include Google classroom, Google meet, Zoom meeting, Office365, Quezzis, WA groups, and Youtube with the material in the form of slides, PDF, and Word. Based on initial observations, learning information was obtained starting with the teachers informing the students about the plans for when learning starts and what platforms to use, mostly through social media WhatsApp, Instagram, and Facebook as many as $81.7 \%$, the rest via SMS and Email. Not all students have computers/laptops or smart gadgets to receive learning and the problem of internet network signal is not evenly distributed in each region. This situation resulted in students not being able to take online lessons well, there were about $70.6 \%$ of students had never attended online lessons so that students missed the lessons carried out on the schedule.

Problems in the online learning process make it difficult for students to understand the material taught by the teacher as shown in figure 1, there are about $86.5 \%$ of students stating that they have difficulty receiving lessons. This difficulty is thought to be because students feel they are experiencing a new learning process that is different from conventional learning in the classroom. Understanding technology also makes them experience difficulties in the learning process. The ownership of the tools to access learning and the limited quota and uneven internet coverage makes it difficult for them to receive lessons.

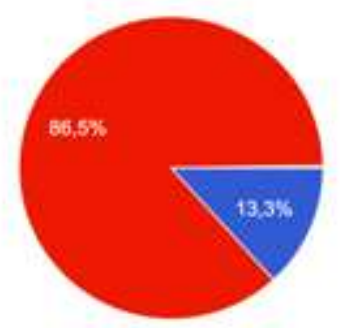

\author{
- Easy to understand the \\ lesson \\ Not understanding the \\ lesson
}

Figure 1. Students' opinions about the obstacles of online learning

The difficulty of receiving learning as above, resulted in a decrease in student achievement up to $52.8 \%$ as illustrated in figure 2 . 


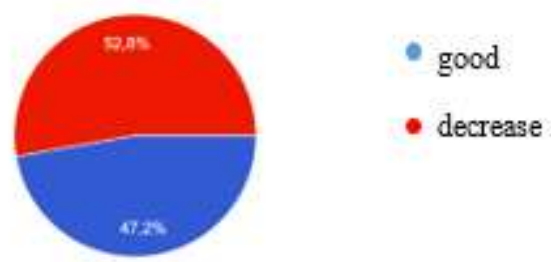

Figure 2. The teacher's opinion about the obstacles of online learning

The decline in the quality of learning at SMP N 6 Semarang due to the Corona-19 pandemic requires a solution in the online learning process. A total of $68.6 \%$ of teachers and $59.1 \%$ of students want all subjects and teaching materials in the school year to be displayed on one learning media. It is expected that students can reopen or repeat the subject matter that has been taught to be studied at a certain time or for students who do not follow the lesson at that time. The desire of students and teachers is as stated by Majid (2011) that learning resources are defined as information materials that are presented and stored in various media that can help students and teachers in learning as the embodiment of a curriculum.

To accommodate all subjects and teaching materials, it is necessary to develop a tool/media in the form of a Learning Management System (LMS), this is as stated by Riad and El-Ghareeb (2009) Learning management system (LMS) is a series of software that Comprehensively integrated into the various features used to deliver and manage courses, the LMS automatically manages the course catalog and quiz features. LMS provides opportunities for teachers and students to interact during the learning process such as during face-to-face learning through features and information compiled by the admin in the LMS.

Amiroh (2012) also said about the Learning Management System (LMS) or Course Management System (CMS), also known as the Virtual Learning Environment (VLE), which is a software application used by educators, both at universities/colleges and universities. school as a means of internet-based online learning media. LMS provides a way out of holding learning during the covid-19 pandemic, because it is done virtually or not face-to-face between teachers and students.

According to Darmawan (2014), a Learning Management System (LMS) is software or software used for administrative purposes, documentation, finding materials, reporting an activity, providing training materials for online teaching and learning activities that are connected to the internet. LMS provides a variety of tools that provide services to make it easier to upload and share teaching materials, online discussions, chatting, administering quizzes, surveys, reports, and so on. LMS can facilitate the documentation of all subjects, materials, and other information in addition to the learning process to support the continuity of education as a whole.

In general, LMS has features that must be met to facilitate the online learning process as stated by Epignosis (2014) that some basic features that must be present in an LMS are: 1) an attractive interface, 2) easy customization. adjust the system according to the user's wishes, 3) virtual classes, 4) connect with learning media, 5) the existence of communication features in the form of forums or chat, 6) courses, 7) reporting.

\section{Material and Methods}

In this study manuscript, the literature method is descriptive-analytical, which is an activity method that aims to describe or provide an overview of the object under study through data or samples that have been collected properly without conducting an analysis or making applicable conclusions for the public, this is as stated by Sugiyono (2012). The data will be studied in the form of literature books, several journal publications, interviews, and questionnaire results as a preliminary study. The stages in this study are to define the scope of the topic to be reviewed, 
identify relevant reference sources, review the literature from relevant books, then analyze all selected and relevant literature in this study.

\section{Results and Discussion}

Learning Management System (LMS) is software for administrative activities, reporting of activities, including also for learning activities and other online activities connected to the internet, as a medium for using e-learning systems and training or course materials. The learning LMS contains the features needed in the learning process, so that LMS managers, teachers, and students can communicate with each other to send or exchange materials or information, they can access it to download or upload materials.

The results of research by Hanum (2013) revealed that overall it was concluded that the implementation of e-learning as a learning medium at the Vocational High School Telkom Sandhy Putra Purwokerto was quite effective with a tendency of $77.27 \%$. This shows that the implementation of e-learning at the Vocational High School Telkom Sandhy Putra Purwokerto is not fully effective for all teachers at the Vocational High School Telkom Sandhy Putra Purwokerto, there are shortcomings due to several factors from the implementation of learning that has not been optimal. This shows that e-learning which is used as online learning is quite effective as a substitute for face-to-face learning, but there needs to be debriefing or training for teachers to present learning materials that students can easily understand the material to be delivered. In the preparation of teaching materials on e-learning must be characterized as conveyed by Clark and Mayer (2008) namely 1) there is content that is relevant to the objectives of the learning process, 2) using instructional methods by presenting examples that are appropriate to life and training to improve the learning process, 3) in delivering material using media elements such as interesting words and pictures, 4 ) it is possible for direct teacher-centered learning (synchronous e-learning) to be designed in learning independently (asynchronous e-learning) (asynchronous e-learning), 5) build understanding and skills related to learning objectives either individually or to improve group learning performance.

It can be said that online learning during the coronavirus or covid-19 pandemic is only a complement to conventional learning because it is impossible to carry out face-to-face learning but if conditions allow normal learning in the classroom, this is as stated by Shank (2008) that elearning plays a role as a complement to conventional or face-to-face classes and not as a substitute for conventional classes. Although as a complement to conventional learning, e-learning has many advantages because it can use mobile devices or tools that are more practical and can move anywhere and anywhere, as stated by Tamimuddin (2007) that there are several advantages of m-learning. which is compared with other teaching and learning processes, namely 1) can be used anytime and anywhere as long as it is still on the internet network, 2) most mobile devices have prices that are still relatively cheap compared to the price of desktop personal computers, making them affordable for the general public. lower middle class or remote areas, 3) The size of the device is small and lighter than a desktop PC can be carried everywhere to get internet access, 4) Supports distance learning, 5) Student-centered learning because they are active in seeking information learning, self-study subjects being taught and actively asking when there are difficulties, 6) must be able to increase interaction between teachers and students because more understanding is needed every time online learning, 7) is expected to be able to involve more students because m-learning utilizes technology that is often used in life. day-to-day, so that everyone can be directly involved and unaffected by space and place. Interactivity in online learning is strengthened as Novak (2010) states that using e-learning can increase interactivity and efficiency in learning because it gives students high potential to communicate more with lecturers, teachers, between students and can access more learning materials. 
Table 1. The differences between e-learning and conventional

E-Learning

Based on students' self-motivation,

Evaluations and assignments depend on the speed of students' comprehension.

Innovative ways are needed to conduct tests and experiments

The length of learning is determined by the student.

The number of students who take online learning is larger.

\section{Conventional}

Teachers play an active role in motivating and educating students.

Evaluations and assignments are carried out according to a predetermined schedule

Test activities and practical experiments are available in the Laboratory

The institution has a fixed schedule and time for subjects

Learning activities are limited in schools or certain institutions

The difference between e-learning and conventional classroom learning in the table above shows the flexibility of online learning with e-learning that can be placed in an LMS. Learning by using LMS provides other learning experience opportunities for students, namely 1) students have more motivation and play an active role in learning compared to face-to-face learning, 2) flexibility and speed in doing exams or assignments according to students' speed, 3) although cannot practice directly in the laboratory, students can explore through modules and links provided by the teacher such as practicum in the laboratory, 4) students can study whenever, wherever and how long they can study, 5) lessons in one session can be followed by more students than conventional classes. Although LMS is a complement to learning, there are advantages compared to conventional learning in the classroom so that it can improve the quality of student outcomes during the current COVID-19 pandemic.

The results of Syamsuar's research (2010) obtained data that in terms of interaction, there was a significant increase where students could take advantage of the communication facilities in the LMS that had been provided, mainly the use of forums or online discussions. Nearly $90 \%$ of lecture participants took part in discussions held on e-learning media. Waryanto (2006) revealed that the advantage of using online learning is that online learning can be used in a learning process that is not limited by space and time. The level of effectiveness in the learning process/lectures using LMS is very helpful for teachers in the learning process, especially knowing the activeness of students in the process with the hope that the material can be absorbed well.

The use of the LMS application can improve student learning outcomes, as research results from Nur Istiyan et al. (2020) obtained data that the use of the LMS application as a learning medium can improve student learning outcomes. This is shown based on student learning outcomes after being given learning media using the LMS application which experienced an increase of $40.79 \%$.

Understanding the concept of providing subject matter through the LMS is very good, as stated by wibowo et al. (2014) the gain test results on understanding the concept of 0.56 in the medium category, meaning that LMS is effective in improving students' conceptual understanding. The use of LMS can improve student learning outcomes. Another result, that students' learning using LMS software was tested using a posttest. Based on the posttest, it was found that there was an increase in the average score of 76.93 students, while the average pretest was 47.61. These data indicate an increase in students' conceptual understanding of physics material after using LMS software. This is following the function of the LMS which can add insight and help students' understanding.

The readiness of the school in dealing with various online learning problems by seeing the importance of LMS in the online learning process as a substitute for face-to-face learning needs to be inventoried so that schools are truly ready for online learning. 


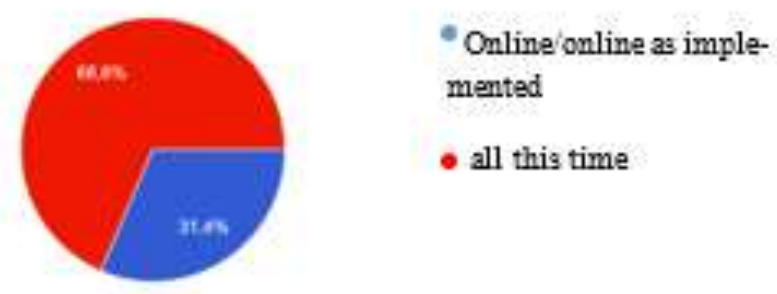

Figure 3. The student's opinion about the desired learning media
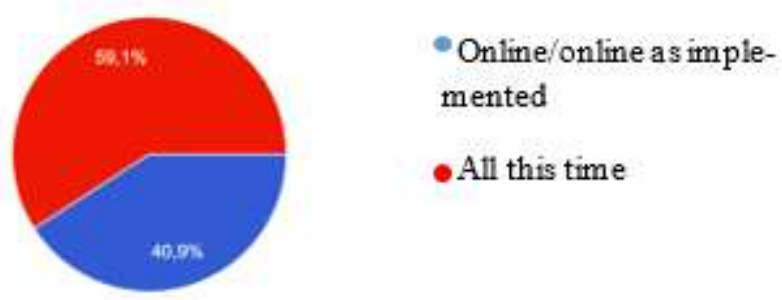

- All this time

Figure 4. The teacher's opinion about the desired learning media

As in the initial survey, there were $68.6 \%$ (diagram 3) of teachers' opinions and $59.1 \%$ (diagram 4) of students' opinions, they expect all lessons and teaching materials in the current academic year to be displayed all on one learning media. So, it is necessary to design or prepare LMS well in the quality learning process so that it is close to face-to-face learning. The limited ability of school infrastructure for LMS media and the limitations of students having computers or the like to take part in learning can be overcome by studying in limited groups.

In the development of LMS, some requirements must be met as expressed by the requirements that must be met as stated by Wahono (2003) that the criteria for media research for learning there are three aspects, namely: 1) engineering aspects of software or program aspects, 2) aspects of learning design or technical quality and program effectiveness, 3) visual communication aspects or program display, with the hope that a program will be realized that can be utilized according to its needs and functions in the online learning process.

In online learning, it is necessary to pay attention to its usefulness as according to Bates (1997) who stated that there are four things: 1) it can increase the level of learning interaction between students and teachers or instructors (enhance interactivity), 2) allows for learning interactions from anywhere and anytime. only (time and place flexibility), 3) can reach students in a broad scope (potential to reach a global audience), 4) can facilitate the refinement and storage of learning materials (easy updating of content as well as archive capabilities).

\section{Conclusion}

The coronavirus or covid-19 pandemic that has hit the world has changed the order of life, including affecting the world of education in the learning process. The world of education gets around this by implementing online learning, where teachers and students do not meet but carry out learning from their respective homes using computers and internet facilities. This requires the teacher's skills to present interesting teaching materials and can be easily absorbed by students, so students are also actively involved in the process so that interaction between teachers and students is realized. The teacher is more active in checking the comments column when there are questions from students so that the answers can be quickly given so that students do not wait too long for answers. 
Referring to the analysis of the above discussion, it can be concluded that although online or distance learning with LMS is very effective in replacing face-to-face learning, it is still not optimal due to the lack of teacher and student skills considering this is a new thing for them, but online learning is considered more than adequate. as a substitute for face-to-face learning. Teachers in presenting teaching materials need to pay attention to the relevance of these subjects in the real world by providing examples in the form of interesting pictures so that there will be an interaction between teachers and students, this will make it easier for students to absorb what is conveyed by the teacher. The estuary of using LMS is as a substitute for face-to-face learning processes but can improve student learning outcomes.

School readiness in infrastructure, teacher skills, and students' ability to use information technology is very important in the online learning process. Aspects in the preparation of the LMS must be met to facilitate the implementation of online learning. With the readiness of all elements of online learning, online learning can be carried out properly and smoothly.

\section{Acknowledgment}

We would like to thank the Principal of State Junior High School 6 Semarang, Mr. Suparno, S.Pd., M.Pd who has allowed me to research by taking preliminary survey data for teachers and students. Mr. Nurkholis, S. Kom is a teacher of informatics and computer engineering who has helped collect preliminary research data from teachers and students.

\section{References}

Amiroh. (2012). Building e-learning with learning management system moodle. Jakarta: Genta Group Production.

Bates, A. W. (1997). Technology, open learning and distance education. London: Routledge.

Clark, R. C., \& Mayer, R. E. (2008). E-Learning and the science of instruction: proven guidelines for consumers and designers of Multimedia learning, second edition. San Francisco: John Wiley \& Sons, Inc

Darmawan, D. (2014). Educational innovation approach to multimedia technology practice and online learning. Bandung: PT Pemuda Rosdakarya Offset

Epignosis, L. (2014). E-Learning concepts. Trend, Applications, ed: version, 2014

Istiyan, N., Nyoto, R. D., \& Muhardi, H. (2020). Learning management system application at madrasah aliyah level. Journal of Systems and Technology, 8(1), 105-115.

Majid, A. (2011). Learning planning. Bandung: Rosdakarya Youth.

Novak, J. (2010). Learning, creating and using knowledge: Concept maps as facilitative tools in schools and corporations. Journal of elearning and Knowledge Society, 6(3), 21-30.

Numiek Sulistyo Hanum. (2013). Keefetifan e-learning sebagai media pembelajaran (studi evaluasi model pembelajaran e-learning SMK Telkom Sandhy Putra Purwokerto). Journal of Vocational Education, 3(1), 90-102. Doi: https://doi.org/10.21831/jpv.v3i1.1584

Riad, A. E. M., \& El-Ghareeb, H. (2009). evaluating of utilizing service-oriented architecture as a suitable solution to align university management information systems and learning management system. Turkish Online Journal of Distance Education, 10(1), 15.

Rusman. (2011). Learning models develop teacher professionalism. Jakarta; PT. Rajagrafindo Persada.

Shank, P. (2008). Thinking critically to move e-learning forward. in S. Carliner \& P. Shank (Eds.), The e-learning handbook: past promise, present challenges. San Francisco: Pfeiffer.

Sugiyono. (2012). Quantitative, qualitative, and $R \& D$ research methods. Bandung: Alphabeta

Syamsuar. D. (2010). Pemanfaatan Learning Management System (Lms) pada matakuliah software quality assurace. Journal of Information Systems (JSI), 2(2), 258-271. Doi: https://doi.org/10.36706/jsi.v2i2.730

Tamimuddin H, M. (2007). Introduction of mobile-based learning media (Mobile learning). Available at https://docplayer.info/40198254, accessed August 5, 2021.

Wahono, R.S. (2003). Introduction to e-learning and its development. Jakarta: Computer Science

Waryanto, N. H. (2006). Online learning is one of the learning innovations. Pythagorean Journal, 2(1), 1-5.

Wibowo, A. T., Akhlis, I., \& Nugroho, S. E. (2014). Pengembangan LMS (Learning Management System) Berbasis Web untuk Mengukur Pemahaman Konsep dan Karakter Siswa. Scientific Journal of Informatics, 1(2), 127-137. Doi: https://doi.org/10.15294/sji.v1i2.4019 